\title{
Lower gastrointestinal malignancy in Crohn's disease
}

\author{
W R Connell, J P Sheffield, M A Kamm, J K Ritchie, P R Hawley, J E Lennard-Jones
}

\begin{abstract}
An increased incidence of carcinoma of the small bowel and colon has been described in patients with Crohn's disease. Tumours arising in the rectum and anus are reported less often. Between 1940 and 1992, of some 2500 patients with Crohn's disease seen at this hospital, 15 are known to have developed carcinoma of the lower gastrointestinal tract. Malignancy occurred in the colon in two patients, in the upper two thirds of rectum in one, in the lower third of rectum in seven, and in the anus in five. The 12 patients with carcinoma arising in the anus or lower rectum had longstanding severe anorectal Crohn's disease, which included a stricture in four, fistula in four, proctitis in one, abscess in two, and enlarged anal skin tags in one. The development of malignancy in patients with Crohn's disease may apply particularly to those with chronic complicated anorectal disease.
\end{abstract}

(Gut 1994; 35: 347-352)

There is growing evidence from epidemiological studies and clinicopathological data obtained from case reports that Crohn's disease is associated with an increased risk of carcinoma of the small and large bowel. In contrast with ulcerative colitis where the risk of colorectal carcinoma is clearly established, the extent of the risk in Crohn's disease remains controversial. Four population based studies have failed to show an increase in the incidence of any type of cancer, including colorectal carcinoma, in patients with Crohn's disease. ${ }^{1-4}$ One population study, ${ }^{5}$ a national survey of 95 American gastroenterologists, ${ }^{6}$ and three other large series from tertiary referral centres ${ }^{7-9}$ describe an increased comparative risk of colorectal cancer in patients with Crohn's disease ranging from $2 \cdot 1$ to $20 \cdot 0$.

Three of four referral based studies have also described an increased incidence of small intestinal cancers in Crohn's disease. ${ }^{6-8}$ The remaining report found no such excess but more gastric carcinomas were found than expected. ${ }^{9}$

In addition, there have been three longterm analyses of the overall incidence of extraintestinal cancers in Crohn's disease and in none has an excess been found, ${ }^{9-11}$ although increases in squamous cell cancer ${ }^{10}$ and lymphomas ${ }^{11}{ }^{12}$ have been reported.

Among the many reports of bowel tumours in Crohn's disease, there have been few describing carcinoma of the anorectal region, anus or in association with anal or rectal fistulas..$^{93-27}$ The risk of developing anorectal carcinoma in Crohn's disease is unknown. Fifteen patients with carcinoma of the colon, rectum or anus have now been seen at this hospital over a 53 year period. Nine have been reported previously. ${ }^{13-15}$
This paper describes our experience of lower gastrointestinal malignancy in Crohn's disease, and because most of the cases have arisen in the anus or lower rectum, all reports of carcinoma in these sites or associated with anal or rectal fistulas have been reviewed.

\section{Methods}

At St Mark's Hospital, a register is maintained of all patients who have been treated for Crohn's disease since 1940. The development of carcinoma of the large bowel or anus in any patient who continued to attend the hospital is recorded. The case notes of patients with such malignancies were reviewed. Of patients who no longer attended the hospital or in whom follow up information was unavailable, clinical details were not sought. The diagnosis of Crohn's disease was established by clinical, radiological, endoscopic or pathological features. The histology slides of the operative specimens from those patients who had radical surgery at this hospital were reviewed. All carcinomas were within areas of Crohn's disease or an associated anal lesion. The duration of disease was calculated from the onset of symptoms to the development of carcinoma.

\section{Results}

Two thousand four hundred and eighty patients with Crohn's disease have been managed at this hospital over a period of 53 years. Approximately $30 \%$ of these patients have attended the hospital in the last two years. Carcinoma of the colon or anus is known not to have occurred in a further $20 \%$ of patients who had proctocolectomy or whose outcome has been previously reported as part of other research projects. Therefore, we have information regarding the presence of lower gastrointestinal malignancy in approximately $50 \%$ of our Crohn's disease population. Fifteen patients are known to have developed 17 malignant tumours of the colon, rectum or anus over this time. Table I summarises the case details. Except for two of the squamous cell carcinomas of the anus, all tumours were diagnosed after 1966.

Two patients developed carcinoma of the colon, one had synchronous tumours of the upper two thirds of rectum, and 12 had malignancy of the lower third of rectum or anus. One patient developed a carcinoma of the anal canal 12 months after a defunctioning colostomy had been performed for intractable anal pain; in retrospect, it is probable that the tumour was already present at the time of operation (Table I: case 8). One patient with a rectal carcinoma had a defunctioning ileostomy for periods of one and 10 years: the more recent stoma had been closed 12 years before the diagnosis of cancer (Table I: 


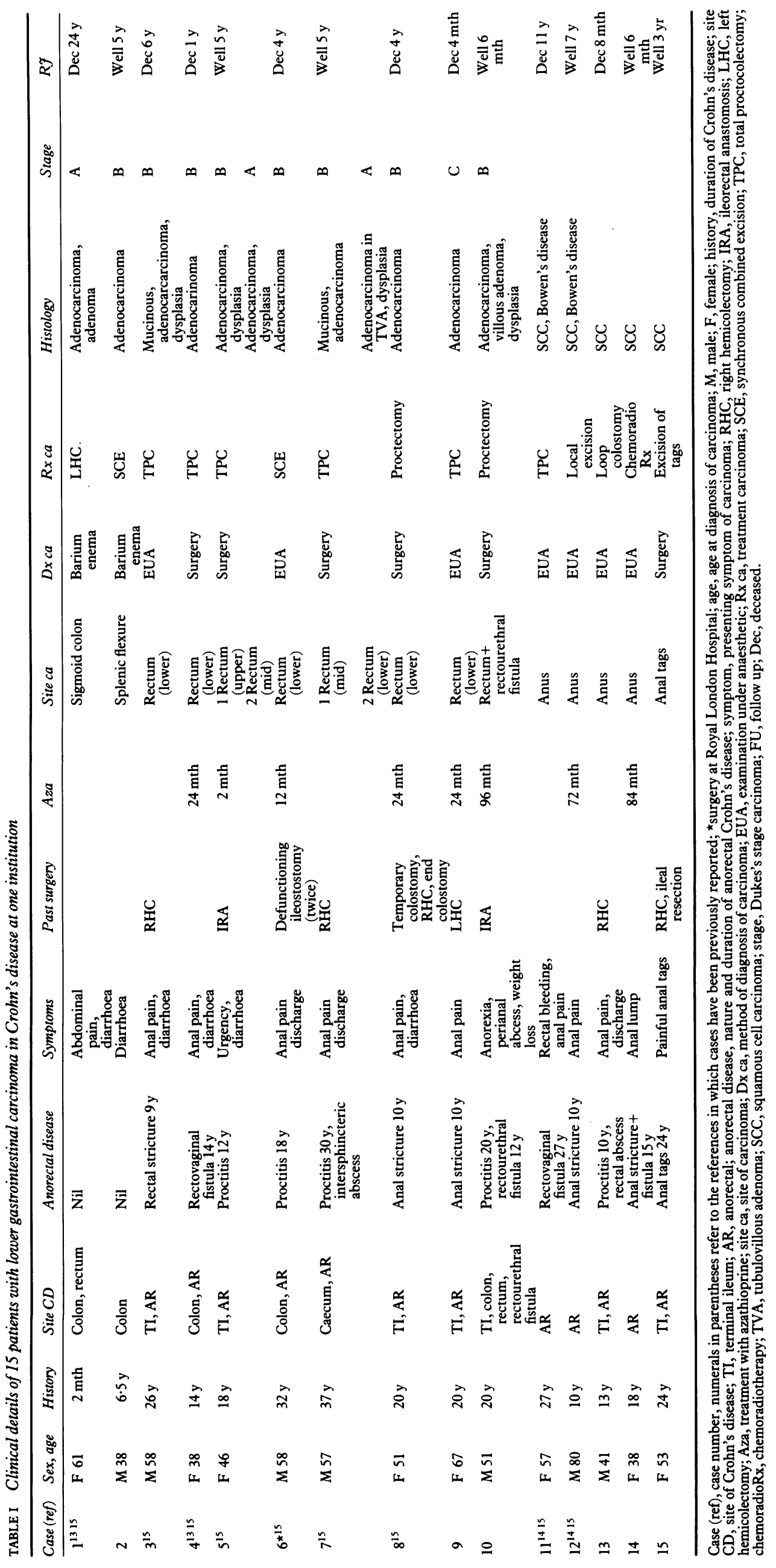

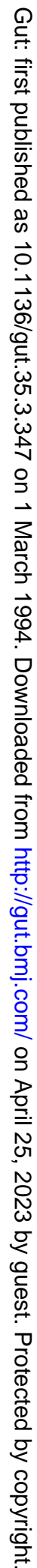


case 6). The patient with synchronous tumours of the upper and middle third of rectum had had a colectomy and ileorectal anastomosis 12 years previously (Table I: case 3).

\section{CARCINOMA OF THE COLON}

The two patients with colonic cancer had symptoms of Crohn's disease for two months and seven years before the diagnosis of carcinoma at ages of 61 and 38 years respectively. Diagnosis in each case was established by barium enema. Both specimens contained granulomas typical of Crohn's disease in association with a predominantly mucosal pattern of inflammation in the region of the carcinoma. There was a moderately dysplastic rectal adenoma in one specimen but no other areas of dysplasia were detected. Both patients had early stage malignancies and survived more than five years.

\section{CARCINOMA OF THE PROXIMAL TWO THIRDS OF RECTUM}

A female patient aged 46 developed synchronous carcinomas of the upper and middle third of rectum 12 years after colectomy and ileorectal anastomosis had been performed for ileocolic Crohn's disease. Moderate proctitis and a rectal stricture was present since the time of surgery and a two month course of azathioprine had been unhelpful. Elective proctectomy was undertaken because of increasing anal pain and urgency that had developed over 12 months. The operative specimen contained an invasive adenocarcinoma of the upper rectum (Dukes's B) with adjacent high grade dysplasia and a smaller adenocarcinoma of the mid rectum arising from a villous adenoma (Dukes's A). The intervening mucosa was inflamed in a predominantly mucosal pattern and although no distinctive features of Crohn's disease were detected on this occasion, review of the original colectomy specimen showed the presence of granulomas. The patient has remained well for five years.

\section{CARCINOMA OF THE LOWER THIRD OF RECTUM}

Seven patients developed adenocarcinomas of the lower rectum: a synchronous carcinoma arising from a villous adenoma of the middle third of rectum occurred in one patient. Four were male and the mean age at cancer detection was 53 years. A longstanding stricture affecting the anus or rectum was present in three cases, a chronic fistula in two, a persistent abscess in one, and severe proctitis in another. The mean duration of Crohn's disease to diagnosis of cancer was 23 years. The development of malignancy was heralded by a deterioration of symptoms in all cases; this included increasing anal pain, faeculent discharge, urgency, incontinence or rectal bleeding over a 6 to 18 month period. One patient with a chronic rectourethral fistula who developed worsening perineal discomfort was subsequently found to have a carcinoma of the rectum affecting the fistulous tract (Figs 1 and 2).

Azathioprine had been given to five patients for a median duration of 24 months (range

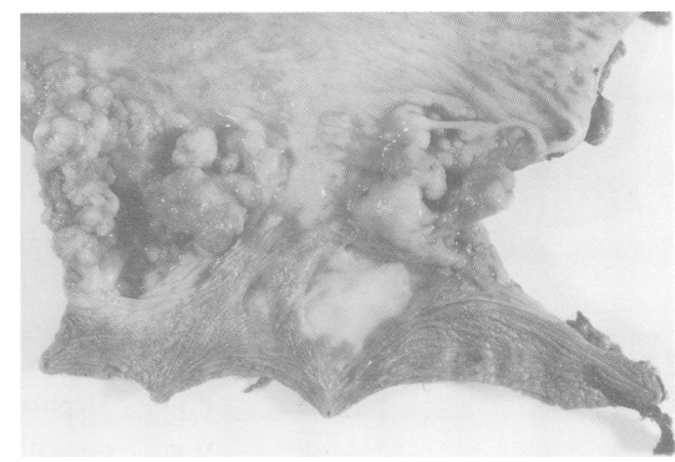

Figure 1: Macroscopic appearance of a patient with carcinoma of the distal rectum associated with a rectourethral fistula.

12-96). One patient with a five year history of éssential thrombocytosis was receiving hydroxyurea when cancer was diagnosed (Table I: case 9). The tumour was found by an examination under anaesthetic in three patients; in two others this examination was negative within a year of the diagnosis of malignancy.

Of seven patients with adenocarcinoma of the lower third of rectum, the pathology specimen was available for review in six. One tumour affected a perirectal sinus, two were associated with fistulas, and three were highly invasive adencarcinomas that disorganised the surrounding architecture. The specimen in which malignancy affected a perirectal sinus exhibited high grade dysplasia along the sinus and a concomitant carcinoma arising from a villous adenoma of the mid rectum. High grade dysplasia was also detected along the fistulous tracts of two other patients whose rectal malignancy were affected fistulas. Five of the carcinomas were mucinous. One was staged Dukes's A, six Dukes's B, and one Dukes's C. All patients had surgical treatment of the tumour, which included proctocolectomy in five, proctectomy in two, and a synchronous combined excision in one. Two patients survived five years or more, four died within five years of cancer detection, and one remains alive 12 months postoperatively.

\section{CARCINOMA OF THE ANUS}

Five patients developed squamous cell carcinoma of the anal canal, one of which affected an

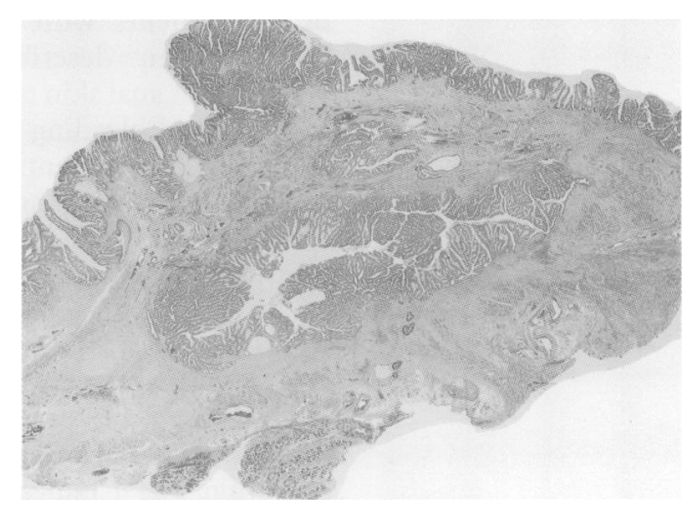

Figure 2: Histological appearance of the same patient as in Figure 1. Note villous dysplasia of the mucosal surface continuing into the fistulous tract. 
TABLE II Patient details of published cases of carcinomas affecting the anorectal region in Crohn's disease

\begin{tabular}{|c|c|c|c|c|c|c|c|}
\hline Case (ref) & Sex, age & Site $C D$ & $C D-c a$ & Site ca & Histology & Treatment & $F U$ \\
\hline $1^{9}$ & $\begin{array}{l}\text { F } 66 \\
\text { M } 29\end{array}$ & $\begin{array}{l}\text { TI, prox colon } \\
\text { Perianal, TI }\end{array}$ & $\begin{array}{l}36 \mathrm{y} \\
17 \mathrm{y}\end{array}$ & $\begin{array}{l}\text { Anal canal } \\
\text { Anorectum }+ \\
\text { perianal fistula }\end{array}$ & $\begin{array}{l}\text { Adenocarcinoma } \\
\text { Mucus secreting, } \\
\text { adenocarcinoma, } \\
\text { adjacent dysplasia }\end{array}$ & $\begin{array}{l}\text { NR } \\
\text { Proctectomy }\end{array}$ & $\begin{array}{l}\text { Dec } \\
\text { Well } 1 \text { y }\end{array}$ \\
\hline $3^{16}$ & F 50 & Ileocolitis & $30 y$ & $\begin{array}{l}\text { Perianal fistula, } \\
\text { sigmoid colon }\end{array}$ & Adenocarcinoma & APR, radiotherapy & $\operatorname{Dec} 2 y$ \\
\hline $4^{17}$ & F 67 & TI, perianal & $22 \mathrm{y}$ & Rectovaginal fistula & $\begin{array}{l}\text { Adenocarcinoma, mucus } \\
\text { secreting, well } \\
\text { differentiated }\end{array}$ & $\begin{array}{l}\text { Proctectomy, } \\
\text { hysterectomy }\end{array}$ & $\operatorname{Dec} 1$ y \\
\hline $5^{18}$ & F 36 & $\begin{array}{c}\text { Ileocolic } \\
\text { perianal }\end{array}$ & $6 y$ & Anorectal junction & In situ cloacogenic & PC & NR \\
\hline $6^{19}$ & F 30 & TI, perianal & $17 y$ & Perianal fistula & Adenocarcinoma & $\begin{array}{l}\mathrm{APR}, \text { vulvectomy, } \\
\text { radiotherapy }\end{array}$ & Dec 1 y \\
\hline $\begin{array}{l}7^{20} \\
8^{21}\end{array}$ & $\begin{array}{l}\text { M } 30 \\
\text { F } 53\end{array}$ & $\begin{array}{l}\text { Perianal, TI } \\
\text { TI, perianal }\end{array}$ & $\begin{array}{l}4 \mathrm{y} \\
10 \mathrm{mth}\end{array}$ & $\begin{array}{l}\text { Anal skin tag } \\
\text { Anal canal }\end{array}$ & $\begin{array}{l}\text { SCC } \\
\text { Cloacogenic }\end{array}$ & $\begin{array}{l}\text { Local excision } \\
\text { Local excision, } \\
\text { radiotherapy, } \\
\text { APR }\end{array}$ & $\begin{array}{l}\text { Well } 9 \text { mth } \\
\text { Dec } 3 y\end{array}$ \\
\hline $9^{21}$ & F 36 & Colon, perianal & $3 y$ & Anal canal & SCC & $\begin{array}{l}\text { Radiotherapy, } \\
\text { APR }\end{array}$ & Well 2 y \\
\hline $10^{21}$ & F 40 & TI, colon, & $14 \mathrm{y}$ & Anal canal & SCC & APR & Recur 2 y \\
\hline $11^{22}$ & M 52 & TI, perianal & $22 y$ & Anorectal junction & $\begin{array}{l}\text { Mucus secreting, } \\
\text { adenocarcinoma }\end{array}$ & $\begin{array}{l}\text { Palliative, } \\
\text { ratiotherapy }\end{array}$ & Dec \\
\hline $12^{22}$ & M 62 & $\begin{array}{l}\mathrm{TI}, \\
\text { anastomosis, } \\
\text { perianal }\end{array}$ & $28 \mathrm{y}$ & $\begin{array}{l}\text { Anorectum, } \\
\text { perianal, fistula }\end{array}$ & $\begin{array}{l}\text { Mucus secreting, } \\
\text { adenocarcinoma }\end{array}$ & Radical excision & Well \\
\hline $13^{22}$ & M 44 & $\begin{array}{l}\text { Ileocolic, } \\
\text { perianal }\end{array}$ & $10 \mathrm{y}$ & Anorectum & $\begin{array}{l}\text { Moderately } \\
\text { differentiated } \\
\text { adenocarcinoma, focal } \\
\text { dysplasia }\end{array}$ & PC & Well \\
\hline $14^{23 \star}$ & F 53 & Colon, perianal & $18 \mathrm{y}$ & Anorectum & $\begin{array}{l}\text { Moderately } \\
\text { differentiated } \\
\text { adenocarcinoma }\end{array}$ & PC & Well \\
\hline $15^{24}$ & F 38 & $\begin{array}{l}\text { Rectum, colon, } \\
\text { perianal }\end{array}$ & $11 \mathrm{y}$ & $\begin{array}{l}\text { Anorectal junction/ } \\
\text { rectovaginal } \\
\text { fistula }\end{array}$ & In situ basaloid & $\begin{array}{c}\text { PC, perineal, } \\
\text { dissection }\end{array}$ & Recur 1 y \\
\hline $16^{25}$ & M 59 & $\begin{array}{l}\text { Perianal, } \\
\text { perinael }\end{array}$ & $30 y$ & Perineal & SCC & $\begin{array}{l}\text { Wide perineal } \\
\text { excision }\end{array}$ & Dec $10 \mathrm{mth}$ \\
\hline $\begin{array}{l}17^{25} \\
18^{25}\end{array}$ & $\begin{array}{l}\text { F } 66 \\
\text { F } 36\end{array}$ & $\begin{array}{l}\text { Ileocolic } \\
\text { Perianal }\end{array}$ & $\begin{array}{l}22 \mathrm{y} \\
25 \mathrm{y}\end{array}$ & $\begin{array}{l}\text { Rectum, perianal } \\
\text { Rectum }\end{array}$ & $\begin{array}{l}\text { SCC } \\
\text { Adenocarcinoma in a } \\
\text { polyp }\end{array}$ & $\begin{array}{l}\text { Radiotherapy } \\
\text { Excision of polyp, } \\
\text { PC }\end{array}$ & $\begin{array}{l}\text { Dec } 6 \mathrm{mth} \\
\text { Well } 3 \mathrm{y}\end{array}$ \\
\hline $19^{26}$ & F 39 & Perirectal & $21 \mathrm{y}$ & $\begin{array}{l}1 \text { Rectum } \\
2 \text { Ascending colon }\end{array}$ & $\begin{array}{l}\text { Undifferentiated } \\
\text { anaplastic carcinoma }\end{array}$ & $\mathrm{PC}$ & Dec few mth \\
\hline $20^{27}$ & F 43 & $\begin{array}{l}\text { Rectum, } \\
\text { perianal }\end{array}$ & $13 y$ & Rectum & Mucoid carcinoma & PC & Dec \\
\hline
\end{tabular}

Prox colon, proximal colon; CD-ca, interval between diagnosis of Crohn's disease and development of cancer; NR, not recorded; APR, abdominaperineal resection; PC, proctocolectomy; rec, tumour recurrence; * patient in ref 23 developed rectal carcinoma 18 years after a defunctioning ileostomy. Other abbreviations as in Table I.

anal skin tag. Three patients were female. The mean age of cancer detection was 52 years and all patients had chronic disease affecting the anorectal region (mean duration 18 years). Two patients had fistulas affecting the anus and rectum, one had a chronic anorectal stricture, one a persistent perianal abscess, and one had grossly enlarged skin tags.

All patients had been reasonably well despite grossly distorted anatomy until they reported increasing anorectal symptoms three to six months before the diagnosis of malignancy. Except for one patient who complained of an anal lump, these symptoms were similar to those seen in the patients with rectal cancer who have already been described. The patient with oedematous anal skin tags complained of increasing pain and bleeding related to the tags before surgery. Two patients had been treated with azathioprine. The diagnosis of malignancy was established at examination under anaesthetic in four cases and by histological examination of the excised anal skin tag in another.

Treatment was surgical in all but the most recent case where chemoradiotherapy was performed (Table I: case 14). In one patient the tumour was inoperable (Table I: case 13) but the operation was a radical procedure in the other three patients. The operative specimen contained Bowen's disease in two cases. Except for the patient with an inoperable tumour who died eight months postoperatively, two patients survived more than five years and two others remain alive six months and three years respectively after treatment for cancer. As the patient who received chemoradiotherapy has been followed up for only a short period, it is premature to assess the efficacy of this treatment in anal cancer related to Crohn's disease.

\section{Discussion}

The first reported case of colorectal carcinoma in a patient with Crohn's disease was described by Warren and Somers in 1948. ${ }^{28}$ Since then, an association between the two conditions has been suggested by the clinicopathological data obtained from over 150 case reports. ${ }^{29}$ The extent of this association has been assessed by incidence studies comparing the risk of colon cancer in patients with Crohn's disease with that expected in the general population. The results of these reports have differed depending on the selection of patients under analysis. ${ }^{1-9}$

Population based studies may give a more accurate assessment than referral based estimates for epidemiological reasons. Five population based studies with follow up periods ranging from 10-40 years have now been done to estimate the risk of malignancy in Crohn's disease ${ }^{1-5}$ Four of these have not shown an increase of any type of cancer. $^{1-4}$ The remaining study, however, 
showed that patients with Crohn's disease had an increased comparative risk of colorectal cancer of $2 \cdot 1$ and for those with Crohn's colitis the risk was $5 \cdot 6 .^{5}$

All four referral based studies have shown that colorectal cancers found in patients with Crohn's disease exceeded that expected for the general population by a factor of $4 \cdot 3-20 \cdot 0 .^{6-9}$ This variability is probably related to the entry criteria of the different studies as patients with an early onset of disease have been shown to be at greater risk of developing colorectal malignancies. ${ }^{30}$

Carcinomas of the small and large bowel in Crohn's disease tend to occur in areas affected by underlying inflammation. Most small intestinal tumours occur in the terminal ileum; in contrast carcinoma of the duodenum or jejununum is more common in the general population. ${ }^{31}$ Hamilton found a similar anatomical distribution of 10 colorectal carcinomas occurring in areas of Crohn's disease with 118 consecutive sporadic cancers of the large bowel. ${ }^{30}$ Most of these were situated in the left colon. In contrast, Stahl et al reported a greater number of right sided colon carcinomas in patients with Crohn's disease than expected in the general population. ${ }^{29}$ Intestinal tumours in Crohn's disease have been reported in association with excluded loops of bowel after bypass surgery,,$^{32}$ strictures, ${ }^{33}$ and internal or external fistulas. ${ }^{25}$

Considerable evidence supports a dysplasiacarcinoma sequence in Crohn's disease. 29303435 Dysplasia adjacent to colorectal carcinoma has been reported in $83-100 \%$ of cases $^{3034} 35$ while dysplasia distant from the cancer has been found in $23-70 \% .{ }^{3034}$ In contrast, only $2 \%$ of colectomy specimens of Crohn's disease without carcinoma contained mild dysplasia. ${ }^{37}$ It has been suggested that the dysplasia-carcinoma sequence occurs as commonly in Crohn's disease as in ulcerative colitis. ${ }^{35}$ The only study that has evaluated surveillance for colorectal cancer in Crohn's disease was undertaken in 356 patients using rectal biopsies: dysplasia occurred in 5\% with a predictive value for colorectal malignancy of $11 \% .{ }^{38}$

More colonic carcinomas in Crohn's disease are poorly differentiated and mucinous compared with sporadic colon malignancies ${ }^{3034} 35$ and, overall, the prognosis is much poorer. ${ }^{35}$

Rectal cancer occurring in Crohn's disease is well recognised but less attention has been given to carcinoma developing in the anal region, lower rectum or in association with anal or rectal fistulas. Only 28 such cases have been described, ${ }^{93-27}$ eight previously reported from this hospital. ${ }^{13-15}$ A further case, without clinical details reported from the Mayo Clinic has been omitted. ${ }^{39}$ Table II summarises the details of the remaining 20. Usually, there had been a long history of anal Crohn's disease: four patients had an anal fistula and two a rectovaginal fistula. The tumour was an adenocarcinoma in 10 patients and squamous cell cancer in five; there was one basaloid tumour, two cloacogenic cancers, and two described only as anaplastic and mucoid carcinomas respectively (Table II: cases 19 and 20). The outcome was generally poor. There is often confusion regarding the precise anatomical site where anorectal carcinomas originate.
Although a tumour may seem to arise from the anus, a pathological report of adenocarcinoma tends to show that the rectum or anorectal junction was primarily affected. Conversely, a so called rectal carcinoma that contains squamous cells is more likely to have originated in the anus. It is often impossible to distinguish adenocarcinomas of the anal canal from carcinomas of the lower rectum, and at our hospital, carcinomas of the anorectal junction are grouped with carcinomas of the lower third of rectum. ${ }^{+0}$ While carcinomas arising in longstanding anorectal Crohn's disease represents a specific clinical problem, the histological distinction may have important therapeutic implications, as squamous cell carcinoma is more responsive to radiotherapy than adenocarcinoma.

Our experience with lower gastrointestinal cancer in Crohn's disease emanates from a highly selected patient population but two features of this report deserve special comment. We feel it is appropriate to distinguish carcinomas arising from the colon and proximal rectum from those occurring in the lower third of rectum or anal canal. The number of colonic and upper rectal carcinomas was much lower than might have been expected though the reason for this remains unclear. We have satisfactory follow up on only part of our Crohn's disease population and had the clinical outcome been pursued in the remaining patients, the number of colon or proximal rectal cancers might well have been higher. Of new patients attending our hospital with an intact gut between 1983-1990, 44\% had disease confined to the colon, 33\% had small and large bowel disease, and 23\% small bowel disease only. ${ }^{41}$ The probability of surgery for colonic Crohn's disease is less than $50 \%$ at 10 years at this hospital, ${ }^{41}$ which is less frequent than that reported elsewhere. ${ }^{42}$ If anything, a higher threshold for surgery is probably associated with an increased incidence of colon carcinoma. The surgical practice of bypass surgery in Crohn's disease is most uncommon at this hospital and no cases of malignancy in excluded intestinal loops have been found. It is our policy to undertake endoscopic surveillance of patients with a history of colonic adenomas. Two of three patients with carcinoma of the colon or proximal rectum associated with Crohn's disease had a concomitant adenoma and it is possible that further cases of cancer development were prevented by this surveillance practice. Histologically, the specimens of the three patients with colonic or proximal rectal tumours contained dysplasia in two cases and a predominately mucosal pattern of inflammation in all three. Because we have not systematically assessed the comparative risk of colon cancer in Crohn's disease, we are unable to make any recommendation regarding surveillance for this malignancy in Crohn's disease.

We do, however, wish to draw attention to the number of lower rectal and anal carcinomas that have been found. A significant proportion of patients attending this hospital with Crohn's disease have evidence of anorectal disease and in part the experience of distal tumours is likely to reflect this referral pattern. The possible reasons for the development of anorectal malignancy in Crohn's disease include chronic inflammation 
and sepsis, immunosuppressive drug use, and viral infection. Carcinomas arising in longstanding anal fistulas in patients without Crohn's disease have been well described. ${ }^{43-44}$ Three of our patients with anorectal tumours had histological evidence of malignancy affecting a fistula or sinus; another two patients with chronic perianal or perirectal fistulas developed invasive carcinomas that obliterated the normal histological architecture. Seven of our patients were treated with azathioprine for up to 84 months: this drug was used in one of the reported cases (Table II: case no 2). ${ }^{15}$ A higher incidence of squamous cell cancers in renal transplant recipients treated with azathioprine has been reported by Kinlen but the longterm effect of this drug in patients with Crohn's disease is not known. ${ }^{45}$ None of the eight patients in our series tested for human papillomavirus (HPV-16) were positive for this virus. ${ }^{15}$ Three of seven specimens of lower rectal carcinoma affected perirectal fistulas or a sinus in which dysplasia was also detected.

In conclusion, carcinomas of the lower third of rectum or anus has been a complication in 12 patients treated for Crohn's disease at St Mark's Hospital over a 53 year period and the possibility should always be borne in mind in patients with Crohn's disease affecting these areas. Many patients with anal lesions have few symptoms despite grossly distorted perianal anatomy. A recent change in symptoms may herald the onset of malignancy. Prophylactic proctectomy, however, cannot be justified in otherwise well patients, as this entails a permanent colostomy and all its disadvantages. We suggest, therefore, that patients with distal disease and chronic anal lesions be monitored regularly for dysplasia or carcinoma. This would entail frequent digital examinations and endoscopy to detect atypical ulceration, induration or stricture formation. Biopsy specimens should be examined for dysplasia. Examination under anaesthetic is indicated if pain precludes normal clinical examination or if an anal biopsy is required. If malignancy is suspected despite a negative examination and biopsy, the investigations should be repeated after a short period of observation. It is hoped tumours can be detected at an earlier and curable stage by this comparatively simple approach.

1 Binder V, Hendriksen C, Kreiner S. Prognosis in Crohn's disease - based on results from a regional patient group from the county of Copenhagen. Gut 1985; 26: 146-50.

2 Kvist $\mathrm{N}$, Jacobsen $\mathrm{O}$, Norgaard $\mathrm{P}$, Ockelmann $\mathrm{HH}$, Kvist HK, Schou G, et al. Malignancy in Crohn's disease. Scand $\mathcal{F}$ Gastroenterol 1986; 21 : 82-6.

3 Gollop JH, Phillips SF, Melton LJ, Zinsmeister AR. Epidemiological aspects of Crohn's disease: a population based study in Olmsted County, Minnesota, 1943-1982. Gut 1988; 29: 49-56.

4 Fireman Z, Grossman A, Lilos P, Hacohen D, Bar Meir S, Rozen P, et al. Intestinal cancer in patients with Crohn's disease: a population study in central Israel. Scand $\mathcal{J}$ Gastroemterol 1989: 24: 346-50.

5 Ekbom A, Helmick C, Zack M, Adami HO. Increased risk of large bowel cancer in Crohn's disease with colonic involvement. Lancet 1990; 336: 357-9.

6 Korelitz Bl. Carcinoma of the intestinal tract in Crohn's disease: results of a survey conducted by the National Foundation for ileitis and colitis. Am f Gastroenterol 1983; 78: 44-6.

7 Weedon DD, Shorter RG, Ilstrup DM, Huizenga KA, Taylor WF. Crohn's disease and cancer. N Engl F Med 1973; 289: 1099-103.

8 Greenstein AJ, Sachar DB, Smith H, Janowitz HD, Aufses AH. A comparison of cancer risk in Crohn's disease and ulcerative colitis. Cancer 1981; 48: 2742-5.

9 Gyde SN, Prior P, Macartney JC, Thompson H, Waterhouse
JAH, Allan RN. Malignancy in Crohn's disease. Gut 1980; 21: $1024-9$.

10 Greenstein AJ, Gennuso R, Sachar DB, Heimann T, Smith H, Janowitz $\mathrm{HD}$, et al. Extraintestinal cancers in inflammatory bowel disease. Cancer 1985; 56: 2914-21.

11 Ekbom A, Helmick C, Zack M, Adami HO. Extracolonic malignancies in inflammatory bowel disease. Cancer 1991; 67: 2015-9.

12 Greenstein AJ, Mullin GE, Strauchen JA, Heimann T, Janowitz HD, Aufses AH, et al. Lymphoma in inflammatory bowel disease. Cancer 1992; 69: 1119-23.

13 Hywel Jones J. Colonic cancer and Crohn's disease. Gut 1969; 10: $651-4$.

14 Preston DM, Fowler EF, Lennard-Jones JE, Hawley PR. Carcinoma of the anus in Crohn's disease. Br f Surg 1983; 70: $346-7$.

15 Gilbert JM, Mann CV, Scholefield J, Domizio P. The aetiology and surgery of carcinoma of the anus, rectum and sigmoid colon in Crohn's disease. Negative correlation with human papillomavirus type 16 (HPV-16). Eur $\mathcal{F}$ Surg Oncol 1991; 17: 507-13.

16 Lightdale CJ, Sternberg SS, Posner G, Sherlock P. Carcinoma complicating Crohn's disease: report of seven cases and review of the literature. $A m \mathcal{F} M$ ed $1975 ; 59: 262-8$.

17 Buchmann P, Allan RB, Thompson H, Alexander-Williams I Carcinoma in a rectovaginal fistula in a patient with Crohn's disease. Am ₹ Surg 1980; 140: 462-3.

18 Daly JJ, Madrazo A. Anal Crohn's disease with carcinoma in situ. Dig Dis Sci 1980; 25: 464-6.

19 Chaikhouni A, Regueyra FT, Stevens JR. Adenocarcinoma in perineal fistulas of Crohn's disease. Dis Colon Rectum 1981; 24: $639-43$.

20 Somerville KW, Langman MJS, Da Cruz DJ, Balfour TW, Sully L. Malignant transformation of anal skin tags in Crohn's disease. Gut 1984; 25: 1124-5.

21 Slater G, Greenstein A, Aufses AH. Carcinoma in patients with Crohn's disease. Ann Surg 1984; 199: 348-50.

22 Ball CS, Wujanto R, Haboubi NY, Schofield PS. Carcinoma in anal Crohn's disease: discussion paper. $\mathcal{F} R$ Soc Med 1988; 81: 217-9.

23 Roe AM, Mortensen NJMcC. Perineal reconstruction with rectus abdominis flap after resection of anal carcinoma in rectus abdominis flap after resection of anal
Crohn's disease. F $R$ Soc Med 1989; 82: 369-70.

24 Lumley JW, Stitz RW. Crohn's disease and anal carcinoma: an association? A case report and review of the literature. Aust NZ F Surg 1991; 61: 76-7.

25 Church JM, Weakley FL, Fazio VW, Sebek BA, Achkar E, Carwell M. The relationship between fistulas in Crohn's disease and associated carcinoma. Dis Colon Rectum 1985; 26: 361-6.

26 Cooper DJ, Weinstein MA, Korelitz Bl. Complications of Crohn's disease predisposing to dysplasia and cancer of the intestinal tract: considerations of a surveillance program. f Clin Gastroenterol 1984; 6: 217-24.

27 Kyle J, Ewen SWB. Two types of colorectal carcinoma in Crohn's disease. Ann R Coll Surg Edinb 1992; 74: 387-90.

28 Warren S, Sommers SC. Cicatrizing enteritis (regional ileitis) as a pathological entity. Am $\mathcal{F}$ Pathol 1948; 24: 475-501.

29 Stahl TJ, Schoetz DJ, Roberts PL, Coller JA, Murray JJ, Silverman ML, et al. Crohn's disease and carcinoma: increasing justification for surveillance? Dis Colon Rectum 1992; 35: 850-6.

30 Hamilton SR. Colorectal carcinoma in patients with Crohn's disease. Gastroenterology 1985; 89: 398-407.

31 Senay E, Sachar DB, Keohane M, Greenstein AJ. Small bowel carcinoma in Crohn's disease. Cancer 1989; 63: 360-3.

32 Greenstein AJ, Sachar DB, Pucillo A, Kreel I, Geller S, Janowitz HD, et al. Cancer in Crohn's disease after diversionary surgery. Am $\mathcal{F}$ Surg 1978; 135: 86-90.

33 Yamazaki Y, Ribeiro MB, Sachar DB, Aufses AH, Greenstein AJ. Malignant colorectal strictures in Crohn's disease. Am $\mathcal{F}$ Gastroenterol 1991; 86: 882-5.

34 Petras RE, Mir-Madjlessi SH, Farmer RG. Crohn's disease and intestinal carcinoma: a report of 11 cases with emphasis on associated epithelial dysplasia. Gastroenterology 1987; 93: 1307-14.

35 Richards ME, Rickert RR, Nance FC. Crohn's diseaseassociated carcinoma. Ann Surg 1989; 209: 764-73.

6 Freko D, Lazarus SS, Dotan J, Reingold M. Early presentation of carcinoma of the small bowel in Crohn's disease ("Crohn's carcinoma"). Case reports and review of the literature. Gastroenterology 1982; 82: 783-9.

37 Warren R, Barwick KW. Crohn's colitis with adenocarcinoma and dysplasia. Am $\mathcal{F}$ Surg Pathol 1983; 7: 151-9.

38 Korelitz Bl, Lauwers GY, Sommers SC. Rectal mucosal dysplasia in Crohn's disease. Gut 1990; 31: 1382-6.

39 Wolff BG, Culp CE, Beart RW, Ilstrup DM, Ready RL. Anorectal Crohn's disease: a long-term perspective. Dis Anorectal Crohn's disease: a

40 Morson BC, Dawson IMP. Morson's and Dawson's gastrointestinal pathology. 3rd ed. Oxford: Blackwell Scientific, 1990

41 Ritchie JK. The results of surgery for large bowel Crohn's disease. Ann R Coll Surg Engl 1990; 72: 155-7.

42 Allan R, Steinberg DM, Alexander Williams J, Cooke WT. Crohn's disease involving the colon: an audit of clinical management. Gastroenterology 1977; 73: 723-32.

43 Winslett MC, Allan A, Ambrose NS. Anorectal sepsis as a presentation of occult rectal and systemic disease. Dis Colon Rectum 1988; 31: 597-600.

44 Nelson RL, Prasad L, Abcarian H. Anal carcinoma presenting as a perirectal abscess or fistula. Arch Surg 1985; 120: 632-5. 45 Kinlen LJ, Sheil AGR, Peto J, Doll RA. Collaborative UKAustralasian study of cancer in patients treated with
immunosuppressive drugs. $B M \mathcal{F} 1979 ; 2: 1461-6$. 